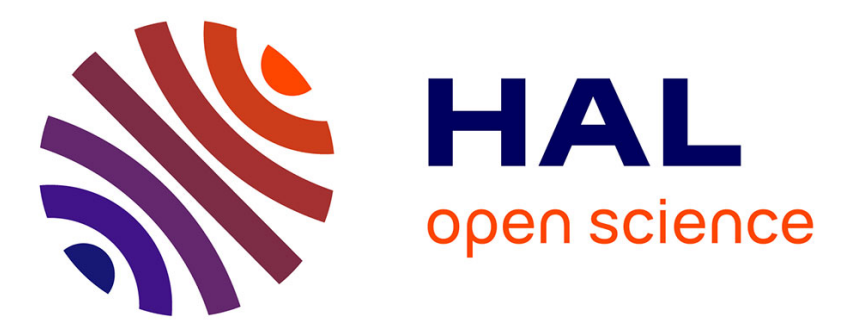

\title{
Synthesis and cellular uptake of superparamagnetic dextran-nanoparticles with porphyrinic motifs grafted by esterification
}

Romain Lucas, Robert Granet, Vincent Sol, Caroline Le Morvan, Clotilde Policar, Eric Riviere, Pierre Krausz

\section{To cite this version:}

Romain Lucas, Robert Granet, Vincent Sol, Caroline Le Morvan, Clotilde Policar, et al.. Synthesis and cellular uptake of superparamagnetic dextran-nanoparticles with porphyrinic motifs grafted by esterification. e-polymers, 2007, 089, pp.089. hal-00685825

\section{HAL Id: hal-00685825 \\ https://hal-unilim.archives-ouvertes.fr/hal-00685825}

Submitted on 6 Apr 2012

HAL is a multi-disciplinary open access archive for the deposit and dissemination of scientific research documents, whether they are published or not. The documents may come from teaching and research institutions in France or abroad, or from public or private research centers.
L'archive ouverte pluridisciplinaire HAL, est destinée au dépôt et à la diffusion de documents scientifiques de niveau recherche, publiés ou non, émanant des établissements d'enseignement et de recherche français ou étrangers, des laboratoires publics ou privés. 


\title{
Synthesis and cellular uptake of superparamagnetic dextran-nanoparticles with porphyrinic motifs grafted by esterification
}

\author{
Romain Lucas, ${ }^{1}$ Robert Granet, ${ }^{1 *}$ Vincent Sol, ${ }^{1 *}$ Caroline Le Morvan, ${ }^{1}$ Clotilde \\ Policar, ${ }^{2}{ }^{3}$ Eric Rivière, ${ }^{2}$ Pierre Krausz ${ }^{1}$
}

1 Laboratoire de Chimie des Substances Naturelles, 123 Avenue Albert Thomas, 87060 Limoges, France; 33-5-55-45-72-02; robert.granet@unilim.fr vincent.sol@unilim.fr

${ }^{2}$ Institut de Chimie Moléculaire des Matériaux d'Orsay, Univ Paris-Sud, UMR 8182 CNRS, Orsay, F91405 Cedex; cpolicar@icmo.u-psud.fr

${ }^{3}$ Equipe de Chimie Bio-organique et Bio-inorganique

(Received: 21 May, 2007; published: 21 August, 2007)

\begin{abstract}
This paper describes new superparamagnetic nanoparticles bearing dextran-grafted porphyrins with effective cellular uptake properties. They average $110 \mathrm{~nm}$ in diameter and are composed of a $5 \mathrm{~nm}$ iron oxide core coated with protoporphyrin-grafted dextrans. These particles show good magnetic properties, are avidly incorporated into cultured cancer cell lines, and thus present a great potential for cellular imaging and photodynamic therapy applications.
\end{abstract}

\section{Introduction}

Photodynamic therapy (PDT) is a type of cancer therapy based on the selective retention of photosensitisers, such as porphyrins, in tumor tissues. Upon irradiation, these photosensitisers are brought to their excited states and generate singlet oxygen. This activated oxygen species seems to be the main initiator of PDT-induced cell damage, [1] yet its mechanism of action is not well understood. [2] Photofrin $I^{\circledR}$ is the first generation photosensitiser which has been the most extensively studied for the treatment of a variety of cancers. [3] However this photosensitiser is not very selective for tumor cells and side effects last for several weeks after treatment. Many efforts have been undertaken for improving tumor cell targeting, for example by grafting sugars, [4] polyamines [5] or oligopeptides [6] which recognize specific cell receptors.

Nanomaterials have attracted much attention in the areas of bio- and medical engineering due to their unique properties. In this way, polymer nanospheres and nanoparticles have been introduced to enhance drug delivery to cancer cells. $[7,8]$ Recently some evidence appeared that particles or clusters in the range of 50-100 $\mathrm{nm}$ penetrate cells more easily than smaller materials. [9] Magnetic nanoparticles offer new opportunities towards developing effective drug delivery systems, as they are easy to produce, characterize and handle. [10] For example, an externally localized magnetic field can be applied to a selected site in order to attract drugloaded magnetic nanoparticles circulating in the blood. [11,12] Although drug targeting is highly desirable, numerous antitumor agents demonstrate non specific toxicities that significantly reduce their therapeutic potentials; in addition, treated 
tumor cells frequently display a multidrug resistance phenotype that is responsible for the failure of chemotherapy. Recent reports have demonstrated that the use of certain drug/polymer coated nanospheres and nanoparticles could, at the same time, improve anticancer drug delivery and overcome multidrug resistance. [13]

In this way, nanoparticles composed of an iron oxide core coated with dextran and bearing photosensitive motifs, like natural or synthetic porphyrins, attracted our attention. These particles benefit from two combined concepts: targeted cancer nanotherapy and photodynamic therapy. This paper reports the first results on the synthesis of superparamagnetic nanoparticles with porphyrins covalently linked by esterification.

\section{Results and discussion}

The general procedure for the synthesis of nanoparticles is described in Fig. 1: (i) the reaction between dextran and porphyrins (esterification), and (ii) co-precipitation of $\mathrm{Fe}(\mathrm{III})$ and $\mathrm{Fe}(\mathrm{II})$ in the presence of $\mathrm{NH}_{4} \mathrm{OH}$ and the functionalized polymers. [14]

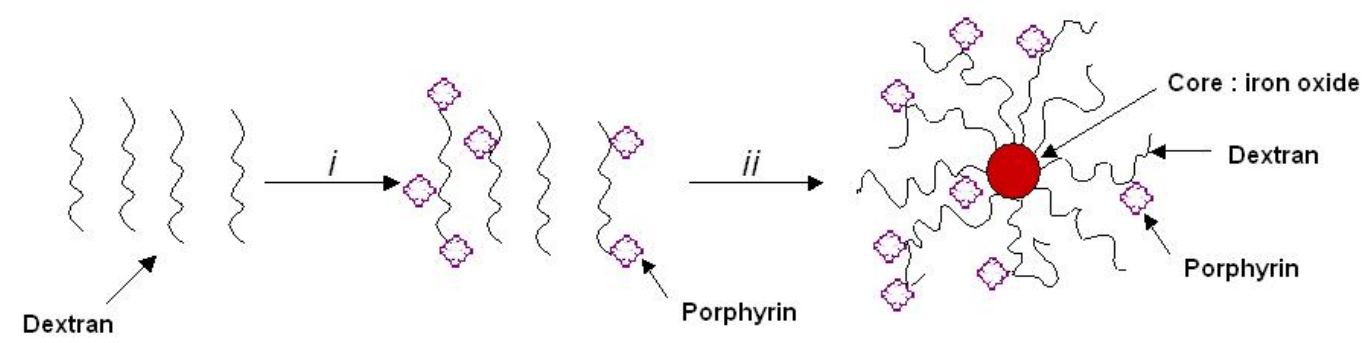

Fig. 1. General process of nanoparticle synthesis: (i) Protoporphyrin, 1,1'-carbonyldiimidazole (CDI), dimethylsulfoxide (DMSO); (ii) $\mathrm{FeCl}_{3}, \mathrm{FeCl}_{2}, \mathrm{NH}_{4} \mathrm{OH}$.

Esterification of dextran by protoporphyrin (commercial PPIX, 30 meq./UAG (anhydroglucose units)) was achieved in dimethylsulfoxide (DMSO) in presence of 1,1'-carbonyldiimidazole (CDI: 2 eq./porphyrin) as electrophilic activator (Scheme 1).

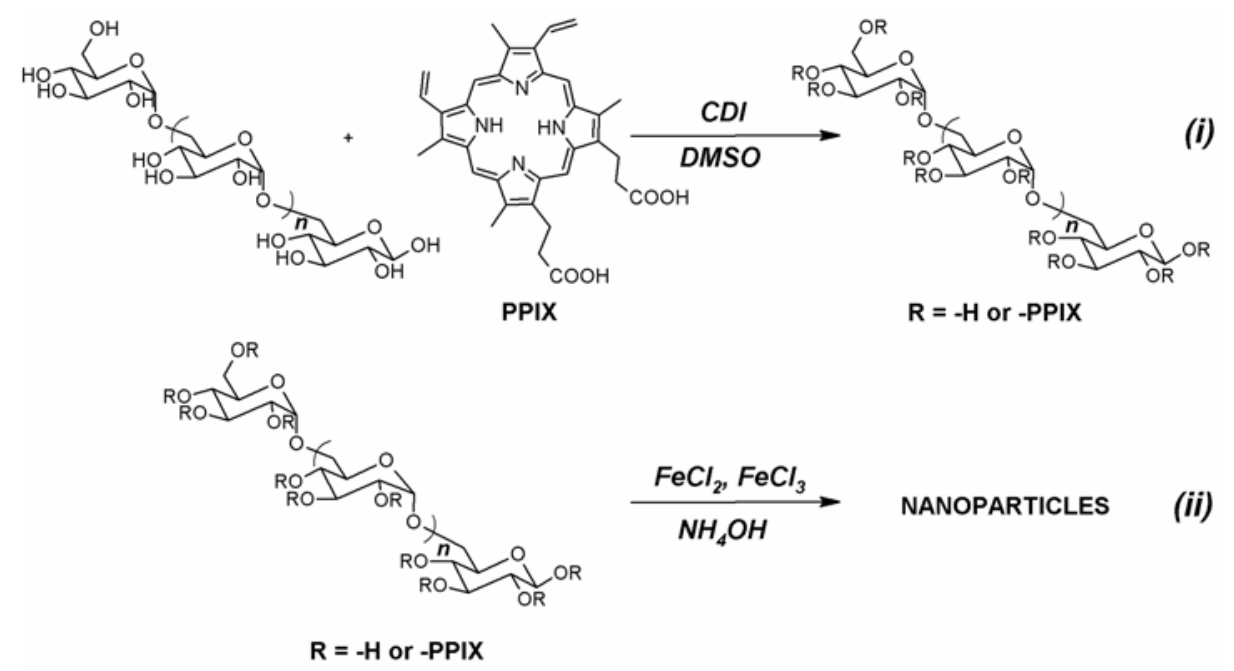

Scheme 1. Nanoparticle synthesis using protoporphyrin. 
Polysaccharides used were 10, 40, 60, 70, 100 and $200 \mathrm{kDa}$ commercial dextrans. Depending on the amount of PPIX, we obtained different degrees of substitution $(D S=$ porphyrins number by UAG) which varied from $0.36 \times 10^{-2}$ to $1.33 \times 10^{-2}$ as determined by UV-visible spectroscopy (Tab. 1 ).

Tab. 1. Mass yield ( $\rho m)$ and degree of substitution (DS) for dextran esterification by protoporphyrin.

\begin{tabular}{ccc}
\hline Dextran $(\mathrm{kDa})$ & $\rho \mathrm{\rho m}(\%)$ & DS $.10^{2}$ \\
\hline 10 & 80 & 1.33 \\
40 & 80 & 0.91 \\
60 & 82 & 0.66 \\
70 & 60 & 0.36 \\
100 & 32 & 0.82 \\
200 & 98 & 0.41 \\
\hline
\end{tabular}

DS should not greatly exceed $1 \%$ to avoid solubility problems or aggregation of the synthesised nanoparticles.

The second step, consisting in the addition of ammonium hydroxide solution to the aqueous mixture containing $\mathrm{FeCl}_{2} / \mathrm{FeCl}_{3}$ and porphyrinic dextran, resulted in the formation of a black solution containing nanoparticles. These nanoparticle solutions were purified by size-exclusion chromatography on Sephadex G75 or G200 depending on dextran molecular weights. The pure nanoparticle fractions were recovered in the first elution peak and then analyzed. UV-Vis spectra (Fig. 2) of dilute nanoparticle solutions showed classical porphyrin patterns, thus attesting macrocycle attachment to the nanoparticles.

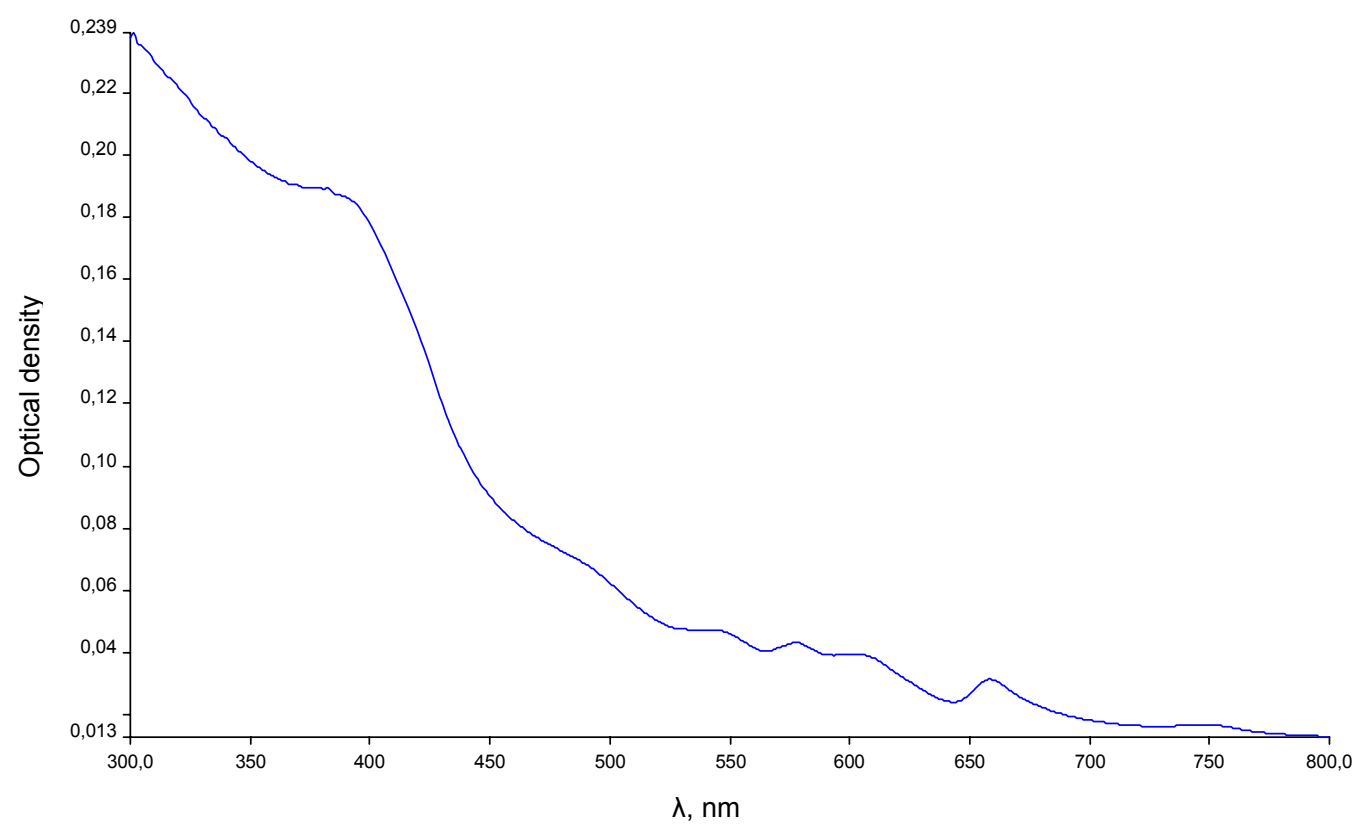

Fig. 2. UV-Vis spectra of Dextran-Protoporphyrin Nanoparticles (40 kDa).

A transmission electronic microscopy (TEM) photograph of a diluted solution of nanoparticles (obtained with $10 \mathrm{kDa}$ dextran) is shown in Fig. 3. 


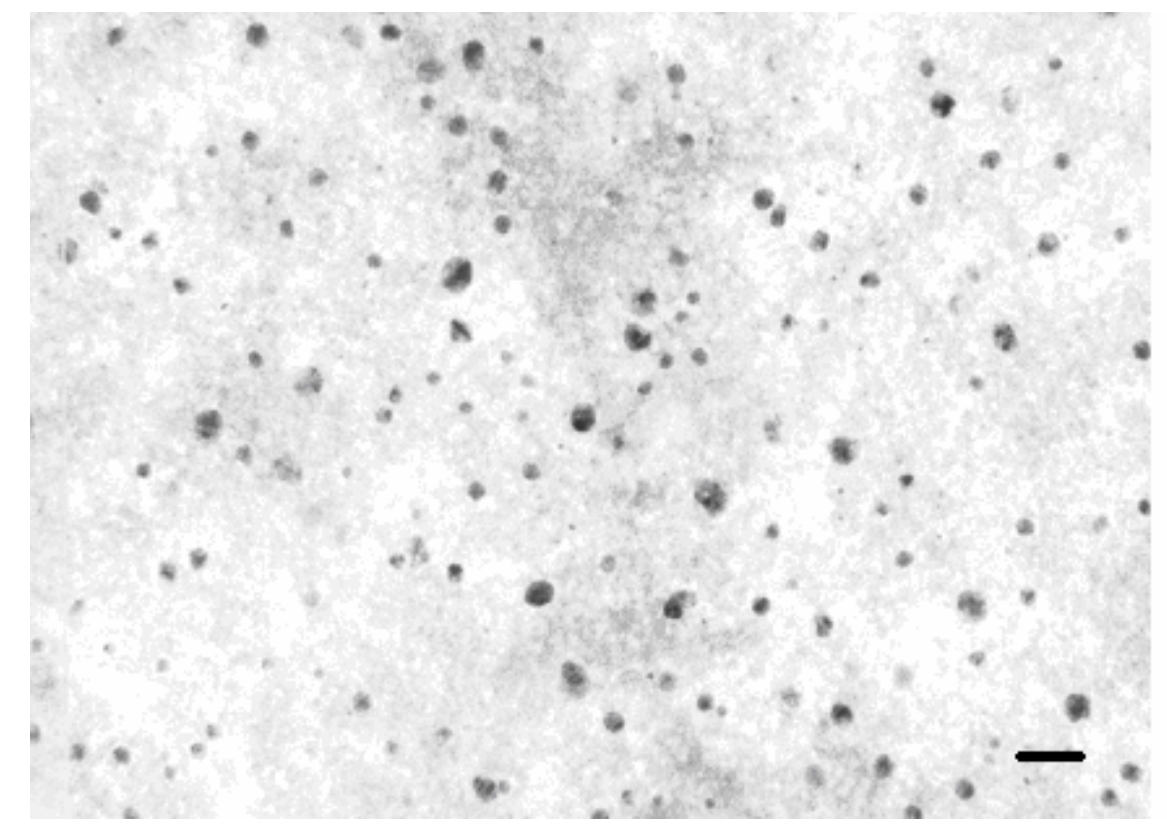

Fig. 3. TEM Photograph of Dextran-Protoporphyrin Nanoparticles (10 kDa). Scale bar: $20 \mathrm{~nm}$.

The electron diffraction pattern indicates that iron oxide cores are made of two types of crystals: magnetite and maghemite (Tab. 2). Size distribution is characterized by a prominence of five nanometer particles. Dynamic light scattering was used to evaluate the hydrodynamic diameter of the external dextran layer containing porphyrins. Measurements on three different nanoparticle suspensions agreed with a Z-average size of $110 \mathrm{~nm}$. This value suggests the occurrence of clusters consisting of several individual nanoparticles as already mentioned by Corr et al. [15]

Tab. 2. Lattice spacings ( $\mathrm{nm}$ ) obtained from powder electron diffraction patterns.

\begin{tabular}{ccc}
\hline Magnetite $^{\mathrm{a}}$ & Maghemite $^{\mathrm{a}}$ & Nanoparticules (10 kDa) $^{-}$ \\
\hline 0.297 & 0.295 & 0.295 \\
0.253 & 0.251 & 0.251 \\
0.210 & 0.209 & 0.209 \\
0.171 & 0.170 & 0.171 \\
0.162 & 0.160 & 0.162 \\
0.148 & 0.147 & 0.148 \\
0.128 & 0.127 & 0.128 \\
0.117 & 0.120 & 0.118 \\
0.102 & 0.104 & 0.102 \\
\hline
\end{tabular}

${ }^{a}$ Obtained from X-ray diffraction data [16]

Magnetization measurements were performed on nanoparticles prepared in the presence of protoporphyrin-modified dextran $10 \mathrm{kDa}$. Both zero-field cooled (ZFC) and field cooled (FC) have been recorded (see Fig. 4), showing very little difference above $32 \mathrm{~K}$. The ZFC measurements indicate a blocking temperature of $22 \mathrm{~K}$. Above this temperature the magnetization curve shows no hysteresis cycle thus indicating a superparamagnetic behaviour of the nanoparticles (Fig. $5, \mathrm{~T}=150 \mathrm{~K}$ and $\mathrm{T}=300 \mathrm{~K}$ ). The hysteresis cycle $(\mathrm{M}=\mathrm{f}(\mathrm{H}))$ was recorded at $5 \mathrm{~K}$, indicating a saturated coercitivity 
$\mathrm{H}_{\mathrm{c}}$ equal to $200 \mathrm{Oe}$ (Fig. 5). These values of coercitivity and blocking temperature are in accordance with the results of Sohn et al.[17] for $\mathrm{Fe}_{2} \mathrm{O}_{3}$ nanoparticles of the same size.

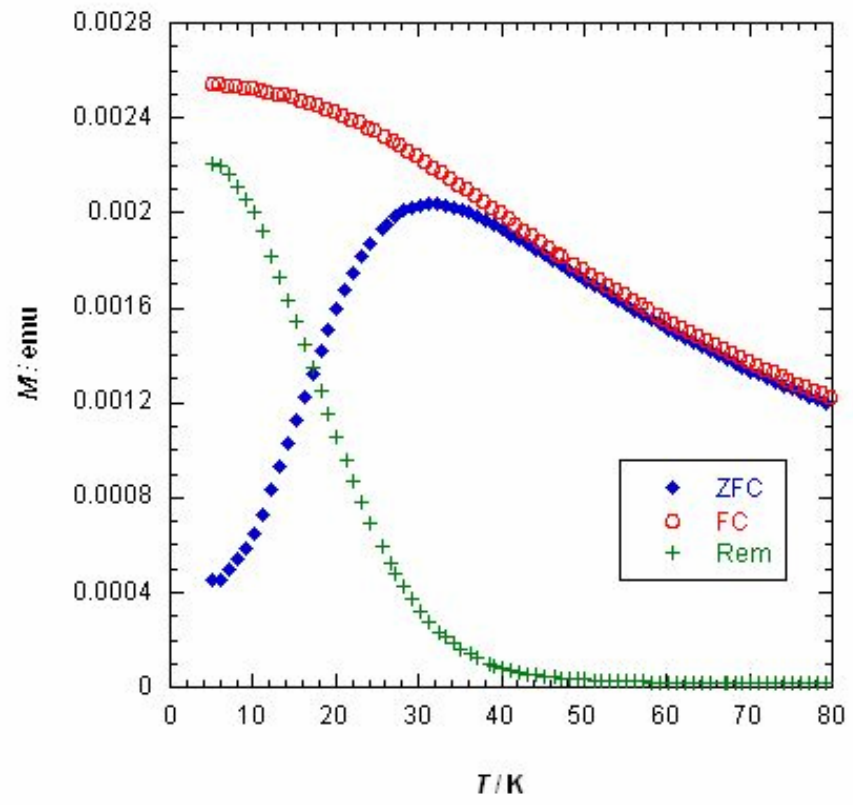

Fig. 4. Magnetization measurements (M). Zéro field cooled (ZFC), Field cooled (FC), Remnant (Rem). $\mathrm{H}=30$ Oe.

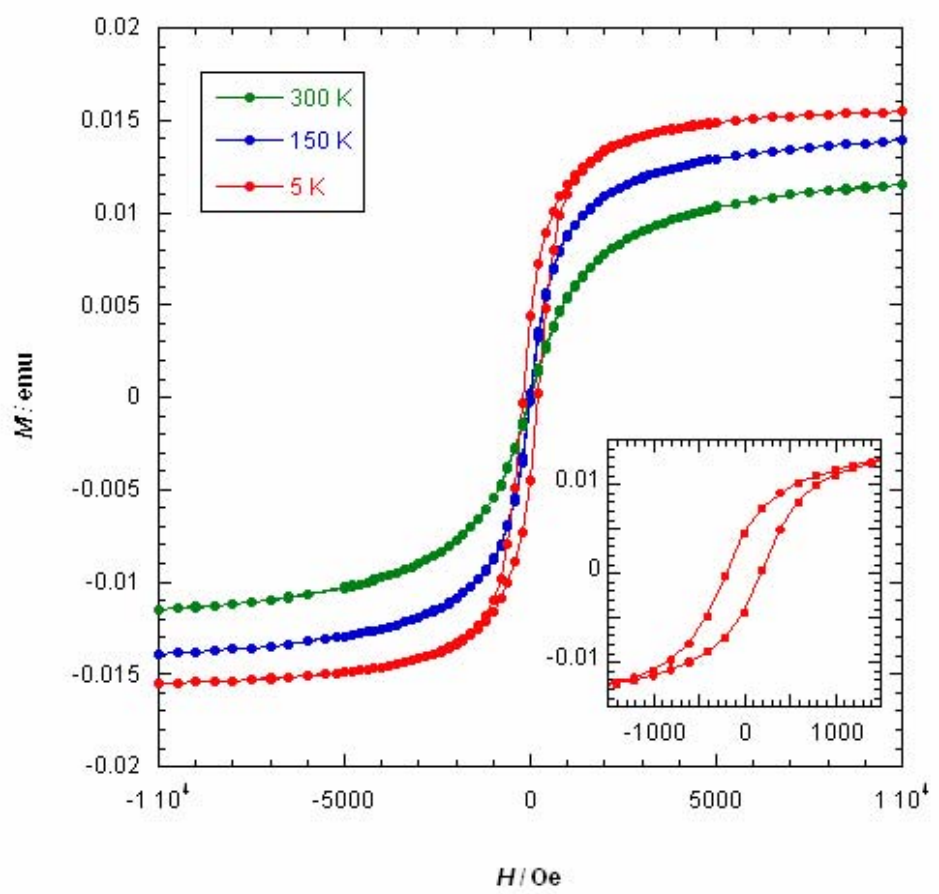

Fig. 5. Hysteresis cycle and superparamagnetic effect $(M=f(H)), T=5 K, 150 K, 300$ $\mathrm{K}$. 
We have investigated the uptake of the nanoparticles from $10 \mathrm{kDa}$ dextran by two cancer lines: MCF7 and HaCat. These adherent cell lines were grown in Eagle's Minimum Essentiel Medium (MEM) and Keratinocytes Serum Free Medium (KSFM) culture media. The cells were incubated with nanoparticles solutions at $6.7 \times 10^{-5}$ mol. $\mathrm{L}^{-1}$ concentration for $30 \mathrm{~min}$ at $37^{\circ} \mathrm{C}$. After washing by PBS solutions the cells were examined by confocal microscopy with excitation wavelength at $514 \mathrm{~nm}$. In both cases the confocal images of the two cell lines show a massive uptake of fluorescent material (Fig. 6). This fluorescence is arising from porphyrin which is readily incorporated in the cytoplasm and several organelles inside the cells. This rapid uptake of the nanoparticles bearing porphyrin by cancer cells make their possible use in photodynamic therapy very promising.
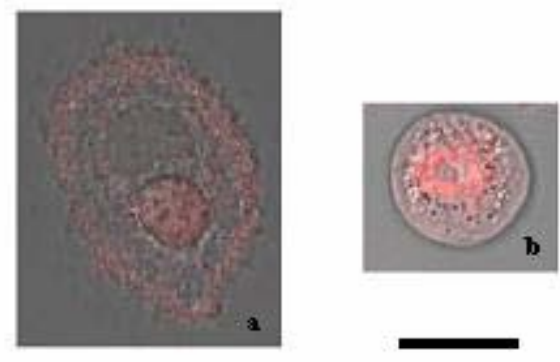

Fig. 6. Confocal fluorescence images of cells incubated with nanoparticles; a, MCF7 and b, HaCat. Scale bar: $1 \mu \mathrm{m}$.

In summary we have prepared new superparamagnetic fluorescent nanocomposites. These materials could be used as diagnostic markers for example in MRI fluorescent confocal imaging. Due to their good ability to penetrate into malignant cell they could be used as photosensitizers in photodynamic therapy applications. Future work will involve PDT in vitro experiments as well as exploring other kinds of porphyrins, dextrans or other polysaccharides.

\section{Experimental}

\section{Materials}

CDI, Ferric and Ferrous salts hydrates, Protoporphyrin IX were obtained from Aldrich. Dextrans were obtained from Fluka and used as received.

\section{Instrumentations}

UV-Vis spectra were recorded on a Perkin Elmer Lambda 25 spectrophotometer.

Dynamic light scattering experiments were performed on a Malvern Instruments Series 4700 system.

Transmission electron microscopy was performed and electron diffraction experiments were realised on JEOL 2010 microscope.

Magnetization measurements were performed using a Quantum Design MPMS-5 SQUID magnetometer.

Confocal microscopy images were obtained by using a zeiss LSM 510 Meta microscope. 
Methods

-General process in synthesis of dextran grafted by protoporphyrin IX (Dextran-PPIX)

$10 \mathrm{kDa}$-Dextran (250 mg, $1.54 \mathrm{mmol}$ of UAG) was dissolved in $3 \mathrm{~mL}$ of DMSO. CDI (14 mg, 2 eq./Porphyrin) and protoporphyrin IX (25 mg, 30 meq./UAG) were then added. The solution was stirred at room temperature during two days. After precipitation with ethanol and filtration, a bright purple solid was isolated $(\rho m=84 \%$, DS $=0.92 \%)$.

-General process for the preparation of nanoparticles

$10 \mathrm{kDa}-$ Dextran-PPIX (135 mg) was dissolved in $7 \mathrm{~mL}$ of deionised water. A mixture of ferric chloride hexahydrate $(100 \mathrm{mg})$ and ferrous chloride tetrahydrate $(30 \mathrm{mg})$ dissolved in $3 \mathrm{~mL}$ of deionised water was added. The mixture was purged under argon, then cooled to $5{ }^{\circ} \mathrm{C}$ overnight. Ammonium hydroxide $(1 \mathrm{~mL})$ was added, and the solution was stirred and heated at $90^{\circ} \mathrm{C}$ for $2 \mathrm{~h}$.

\section{-Magnetic and hysteresis measurements}

The samples (ca. $60 \mu \mathrm{L}$ ) were sealed under vacuum in a quartz glass tube. Zero-field cooled (ZFC) magnetization of each sample was measured by cooling down the sample to $5 \mathrm{~K}$ in zero-field and monitoring the magnetization of the sample from 5 to $100 \mathrm{~K}$ (to maintain a frozen state for the solution) in a field of $30 \mathrm{Oe}$. The field cooled was measured by cooling the sample down to $5 \mathrm{~K}$ in a 30 Oe field and monitoring the magnetization from 5 to $100 \mathrm{~K} . \mathrm{M}=\mathrm{f}(\mathrm{H})$ was recorded at $5 \mathrm{~K}, 150 \mathrm{~K}$ and $300 \mathrm{~K}$.

\section{-Cellular uptake}

MCF7 and HaCat adherent cell lines were grown in MEM and KSFM culture media. Nanoparticles were stabilized for two hours in fresh culture media and then added to cell cultures, at a final porphyrin concentration of $6.7 \times 10^{-5} \mathrm{~mol} . \mathrm{L}^{-1}$. After a $30 \mathrm{~min}$ incubation at $37{ }^{\circ} \mathrm{C}$, the plates were washed several times with PBS and examined by fluorescence confocal microscopy (excitation wavelength: $514 \mathrm{~nm}$ ).

\section{Acknowledgements}

The authors thank the "Laboratoire d'Immunologie de Limoges" for using confocal imaging facility, the "Service de Microscopie Electronique de I'Université de Limoges" for the use of TEM and Dr. Vesteghem of ENSCl (Limoges) for Dynamic Light Scattering experiments. We also thank Pr. Guilloton for editing suggestions. We thank also the "Conseil regional du Limousin" for financial support.

\section{References}

[1] (a) Ochsner, M. J. Photochem. Photobiol., B. 1997, 39, 1-18; (b) DeRosa, M. C.; Crutchley R. J. Coord. Chem. Rev. 2002, 233-234, 351-371.

[2] Sharman, W. M.; Allen, C. M.; Van Lier, J. E. Methods Enzymol. 2000, 319, 376400.

[3] Furuse, K.; Fukuoka, M.; Kato, H.; Horai, T.; Kubuta, K.; Kodama, N.; Kusunoki, Y.; Takifuji, N.; Okunaka, T.; Konaka, C. J. Clin. Oncol., 1993, 11, 1852-1857.

[4] (a) Maillard, P.; Guerquin-Kern, J.L.; Huel, C.; Momenteau, M. J. Org. Chem., 1993, 58, 2774-2780; (b) Li, G. ; Pandey, S.K. ; Graham, A.; Dobhal, M.P.; Mehta, 
R.; Chen, Y.; Gryshuk, A.; Rittenhouse-Olson, K.; Oseroff, A.; Pandey, R.K. J. Org. Chem., 2004, 69, 158-172; (c) Sol, V.; Chaleix, V.; Champavier, Y.; Granet, R.; Huang, Y-M; Krausz, P. Bioorg. Med. Chem., 2006, 14, 7745-7760.

[5] Sol, V.; Lamarche, F.; Enache, M.; Garcia, G.; Granet, R.; Guilloton, M.; Blais, J.C.; Krausz, P. Bioorg Med. Chem., 2006, 14, 1364-1377.

[6] (a) Sol, V.; Blais, J.C.; Carré, V.; Granet, R.; Guilloton, M.; Spiro, M.; Krausz, P. J. Org. Chem., 1999, 64, 4431-4444; (b) Chaleix, V.; Sol, V.; Guilloton, M.; Granet, R.; Krausz, P. Tetrahedron Letters, 2004, 45, 5295-5299; (c) Titand, L.; Frochot, C.; Vanderesse, R.; Thomas, N.; Trinquet, E.; Pinel, S.; Viriot, M.-L.; Guillemin, F.; Barberi-Heyob, M. J. Controlled Release, 2006, 111, 153-164.

[7] (a) Kreuter, J. Adv. Drug. Delivery Rev., 2000, 47, 65-81; (b) Roy, I.; Ohulchanskyy, T.Y.; Pudavar, H.E.; Bergey, E.J.; Oseroff, A.R.; Morgan, J.; Dougherty, T.J.; Prasad, P.N. J. Am. Chem. Soc., 2003, 125, 7860-7865.

[8] (a) Brigger, I.; Dubernet, C.; Couvreur, P. Adv. Drug. Delivery Rev., 2002, 54, 631-651; (b) Imahori, H.; Arimura, M.; Hanada, T.; Nishimura, Y.; Yamazaki, I.; Sakata, Y.; Fukuzumi, S. J. Am. Chem. Soc., 2001, 123, 335-336; (c) Drain, C.M.; Smeureanu, G.; Patel, S.; Gong, X.; Garno, J.; Arijeloye, J. New J. Chem., 2006, 30, 1834-1843.

[9] (a) Osaki, F.; Karramoni, T.; Sando, S.; Sera, T.; Aoyama, Y. J. Am. Chem. Soc., 2004, 126, 6520-6521; (b) Home, C. D.; Walker P.I.; Evans-Gowing, R.; Fitzgerald, S.; Beeby, A.; Chambrier, I.; Cook, M.J.; Russel, D. Langmuir, 2002, 18, 2985-2987. [10] (a) Jolivet, J.P.; Charréac, C.; Tronc, E. Chem. Commun., 2004, 481-487 ; (b) Bertorelle, F.; Wilhelm, C.; Roger, J.; Gazeau, F.; Ménager, C.; Cabuil, V. Langmuir, 2006.

[11] Alexiou, C.; Arnold, W.; Klein, R.J.; Purah, F.G.; Hulin, P.; Bergemann, C.; Erhardt, W.; Wagenpfield, S.; Lubbe, A.S. Cancer Res., 2000, 60, 6641-6648.

[12] (a) Alexiou, C .; Schmidt, A.; Klein, R.J.; Hulin, P.; Bergemann, C.; Arnold, W. J. Magn. Mater., 2002, 252, 363-366; (b) Gu, H.; Xu, K.; Yang, Z.; Chang, C.; Xu, B. Chem. Commun. 2005, 4270-4272.

[13] Lemarchand, C.; Couvreur, P.; Besnard, M.; Costantini, D.; Gref, R. Pharm. Res., 2003, 20, 1284-1292.

[14] Paul, K.G.; Frigo, T.B.; Groman, J.Y.; Groamm, E.V. Bioconjugate Chem., 2004, 15, 394-401.

[15] Corr, S.A.; Byrne, A.; Gun'ko, Y.K.; Gish, S.; Brongham, P.F.; Mitchell, S.; Volkov, Y.; Prina-Mello, A. Chem. Commun., 2006, 4474-4476.

[16] Cornell, R.M.; Schwertmann, U. The Iron Oxides, VCH, Weinheim, 1996.

[17] Sohn, B.H.; Cohen, R.E;. Papaefthymiou, G.C. J. Magn. Magn. Mater., 1998, 182, 216-224. 